\title{
İbn Dakîki'l-Îd ve Şerhu'l-Erba'īne Hadîsen En-Nebeviyye Adlı Eseri Bağlamında Hadis Şerh Metodu
}

\author{
Muhammed Akdoğan* \\ İzmir Katip Çelebi Üniversitesi \\ İslami İlimler Fakültesi \\ orcid.org/0000-0003-0314-0095
}

$\frac{\text { Gönderilme Tarihi }}{04.02 .2019}$

Kabul Tarihi

04.09.2019

\section{$\ddot{O} z$}

Mutlak müctehid olarak nitelendirilen İbn Dakîki'l-Îd, eğitimine ilmî bir aile ortamında başlamış ve hadis, fikıh gibi ilimlerde önemli âlimlerden istifade etmiştir. Öğretim faaliyetine memleketi Kûs'ta başlayan şârih, ardından önemli medreselerde dersler takrir etmiştir. O, Mâlikî fikhı yanında Şâfî fikhında da yetkin hale gelmiş ve her iki mezhebe göre de içtihatta bulunmuş önemli bir ilim adamıdır. Özellikle ahkâm hadislerinin anlaşılmasına dönük olarak aralarında elİhkâm ve el-ïlmâm'ın da bulunduğu birçok eser yazmasının yanında ulemâ arasında revaç bulan Nevevî'nin el-Erbaûn'unu da şerh etmiştir. Genel olarak İslâm'a dair küllî kaideleri konu edinen kitaptaki hadisleri müellif, yeri geldikçe hadis, fikıh, lügat ve Kelâm ilmi noktasından açıklamıştır. Ancak onun bu açılamalara yer vermesinin temel nedeni hadisin doğru anlaşılmasına ve yorumlanmasına dair taşıdı̆̆ı kanaatidir. Özellikle şerhte âyet ve hadisle istişhâd metoduna çokça yer vermiş, bahis konusu edilen hadisle ilgili olarak mezhebî farklliklara temas etmiştir. Eserin tasnifinde sadece hadisçilerin değil aynı zamanda fakih, mutasavvıf, müfessirlerin görüşlerinden de faydalanması eserin önemini artıran bir etken olmuştur. İbn Dakiki'l-Îld'in bu eseri dışında da ahkâm hadislerine dair yaptığı şerhler bulunmaktadır. Bu çalışmada makale boyutuna aşmaması düşüncesiyle sadece bu eseri bă̆lamında eserin yapısal özellikleri, müellifin hadis şerh metodu ve kaynakları tespit edilmeye çalışılmıştır. Hadislerin açıklanması bağlamında Lügat, Hadis, Fıkıh ve Kelâm ilminin kapsamına giren çeşitli konulara temas ettiği görülmüştür.

Anahtar Kelimeler: Hadis, Şerh, İbn Dakîki'l-Îd, Nevevî, Şerhu'l-Erba'īne Hadîsen enNebeviyye.

\section{Ibn Dakīk Al-Īd and Hadıth Commentary Method in the Context of His Study Sharh Al-Arbaīn Hâdīsan Al-Nabaviyyah}

\section{Abstract}

Ibn Dakik Al-İd, who is considered to be the absolute mujtahid, started his education in a scientific environment and benefited from the important scholars in the sciences such as hadith and figh. He started teaching in his hometown of Küs, and then gave lessons in important madrasahs. He became proficient in Shafi'iyya figh besides Mālikiyya figh and He is an important scholar who has made jurisprudence according to both sects. Especially in order to understand the hadiths of ahkām, he wrote many commentaries, including al-Ihkām and al-Ilmām. In addition to his work, he also expounded the Nawawi's el-Erbaûn, which is famous among scholars. The author generally explained the hadiths in the book, which contains the general principles of Islam, from hadith, figh, and vocabulary and theology science. Especially, he profits by evincing method in verse and hadith widely in commentary and he touched on the different opinions of sects about the hadith researched. In the classification of the work, he not only benefit from hadith scholars, but also views of jurits, commentators, mystics and thus, the importance of the work has increased. Apart from Ahmet's this work, there are commentaries he made about ahkâm hadiths. In this study, only the structural features of the work, the hadith commentary method and sources of the 
work have been tried to be determined in the context of this work. In the context of the disclosure of hadiths, it has been observed that it has come into contact with various subjects which are covered by the lexicography, hadith, jurisprudence and theology science.

Keywords: Hadith, Commentary, Ibn Dakīk Al-Īd, an-Nawawī, Sharh al-arbaīn.

\section{Giriş}

"Şerh" kelimesi sözlükte "eti kesmek, parçalara ayırmak ve sözün kapalı kısımlarını açıklamak" gibi manalara gelmektedir. Hadis terimi olarak ise, "bir hadisin veya bir hadis kitabında yer alan rivâyetlerin kelime ve kavramlarını açıklamak, anlaşılması zor yerlerini izah etmek, i'rabını yapmak, hadisten çıkan hükümlere yer vermek" anlamlarında kullanılmaktadır (İbn Manzûr, ty, s.2228; Zebîdî, 1969, s.502-6; Çakan, 2016, s.181-2; Aydınl,, 2009, s.293). Hadislerin şerhi meselesini Hz. Peygamber'in hayatta olduğu zamana kadar götürmek mümkündür. Sözlerindeki bazı kelimelere sahâbe muttali olamamış ve bunun üzerine Hz. Peygamber sözlerine açıklık getirmiştir. Bu kapsamdaki faaliyetler sonraki yıllarda diğer nesiller tarafından devam ettirilmiş ve bir nevi şerh faaliyeti olarak kabul edilen Garîbu'l-Hadîs'ler meydana getirilmiştir. Ancak bildiğimiz anlamda hadisleri şerh etme geleneğinin IV/X. asırda başladığı kabul edilmektedir. Her ilmin ve bu ilimlerin alt kollarının belirli bir seviyeye ulaşması için zamana ihtiyaç duyduğu ehlinin malumu olduğu üzere aynı durum şerh için de geçerlidir. İlk zamanlarda hadisin metnindeki garîb kelimeler izah edilmiş, daha sonra Buhârî (ö. 256/870), Müslim (ö. 261/875), Tirmizî (ö. 279/892) gibi temel hadis kaynaklarında geçen tüm hadisler şerh edilmiş ve son olarak da temel hadis eserlerinde geçen hadislerden seçilerek bir araya getirilen derleme çalışmaların açıklanması faaliyeti yapılmıştır (Türcan, 2008, s.7-47; Karacabey, 1990, s.208-10; Türcan, 2011, s.341-50; Şensoy, 2010, s.555; Efendioğlu, 2010, s.559). Kırk hadise dair eserler de derleme diyebileceğimiz çalışmalardandır.

Makale çerçevesinde konunun anlaşılmasına katkı sunması maksadıyla İbn Dakîk'il-Îd'in hayatı ve ilmî şahsiyeti hakkında kısa bilgi verilecek, daha sonra ise eserde takip edilen hadis şerh metodundan bahsedilecektir.

\section{2. İbn Dakîki'l-Îd'in Hayatı ve İlmî Şahsiyeti}

Tam adı Ebu'l-Feth Takiyyüddîn Muhammed b. Alî b. Vehb b. Mutî' İbn Dakîki'l-Îd es-Saîdî el-Kuşeyrî el-Besecî el-Menfelûtî el-Misrî el-Mâlikî eş-Şâfiî olup 25 Şa'bân 625 (30 Temmuz 1228) senesinde babasının hac yolculuğu zamanında Yenbu'da doğmuştur. O, Behz b. Hakîm el-Kuşeyrî'nin neslindendir (İbn Abdülhâdî, 1996, s.265; Zehebî, ty, s.1481; 1988, s.250-1; Üdfüvî, 1966, s.570, 572; Yâfî̀, 1997, s.177; Safedî, 2000, s.137-8; Sübkî, 1964, s.209; İbn Hacer, ty, s.91-2). Âlim babası hacta Ka'be'yi tavaf ederken onun ilmiyle amel eden bir âlim olması için dua etmiştir (Üdfüvî, 1966, s.570;1 Sübkî, 1964, s.209).

İbn Dakîdi'l-Îd Mısır, Şâm, ve Hicâz'a rıhle gerçekleştirerek babası Mecdüddîn Alî b. Vehb (ö. 667/1269), İbnu'l-Mukayyer (ö. 643/1245), İbnü'l-Cümmeyzî (ö. 649/1251), İbn Revâc (ö. 648/1250), İbnu'l-Hubâb (ö. 648/1250), Abdülazîm b. Abdülkavî el-Münzirî (ö. 656/1258), Ahmed b. Abdüddâim el-Makdisî'nin (ö. 668/1269) 
de aralarında bulunduğu pek çok âlimden hadis dinlemiştir (İbn Abdülhâdî, 1996, s.265; Zehebî, 1988, s.251; Üdfüvî, 1966, s.570-1; Kütübî, 1973, s.443; İbn Hacer, ty, s.92). Kendisine talebelikte bulunanlar arasında İbnü'l-Esîr el-Halebî (ö. 671/1273), Kutbuddîn el-Halebî (ö. 735/1335), İbn Seyyidünnâs (ö. 734/1334), Zehebî (ö. 748/1348), Mizzî (ö. 742/1341), Kâsım b. Yûsuf et-Tücîbî (ö. 730/1329) ve İbn Rüşeyd (ö. 721/1321) gibi önemli âlimler yer almaktadır (İbn Abdülhâdî, 1996, s.265; Zehebî, ty, s.1482; Üdfüvî, 1966, s.572; İbn Ferhûn, 1972, s.318; İbn Hacer, ty, s.92).

İlk eğitimine Kûs medresesinde başlayan İbn Dakîki'l-Îd, Mâlikî fıkhını babasından, Şafiî fikhını ise Bahâuddîn Hibetullah el-Kıftî (ö. 697/1298) ve İzzeddîn b. Abdisselâm'dan (ö. 660/1261) tahsil etmiştir (Üdfüvî, 1966, s.575; Yâfiî, 1997, s.178; Safedî, 2000, s.138; Sübkî, 1964, s.210). Bu hocaları vesilesiyle her iki mezhepte de uzmanlaşmış, hatta Şâfiî mezhebinde Şâfiî̀'nin iki mesele ile ilgili içtihadı hariç diğer meselelerde onunla aynı görüşü paylaşması onun fıkhını anlama ve kavramadaki yerinin bir göstergesi olarak kabul edilebilir. Hadis ve Fıkıh ilminin yanı sıra Tefsir, Kelâm, Arap Edebiyatı gibi alanlarda da kendini yetiştirmiş hatta şiirler yazmıştır (Üdfüvî, 1966, s.575; Safedî, 2000, s.137-8, 141-7; Sübkî, 1964, s.214-30; İbn Ferhûn, 1972, s.318; Kütübî, 1973, s.443-450; Şevkânî, 2012, s.230).

Eğitiminin ardından Kûs'ta Necîbiyye medresesinin müderrisliği görevine atanmış ve aynı zamanda bu yerin Mâlikî kâdılı̆̆ını üstlenmiştir (İsnevî, 1987, s.102; İbn Dakîki'l-Îd, 2006, s.5). Buradan ayrıldıktan sonra Necîbiyye, Nâsırıyye, Fâziliyye ve Kâmiliyye medreselerinde hocalık vazifesiyle görevlendirilmiştir (İsnevî, 1987, s.102; İbn Kesîr, 1997, s.30; İbn Rüşeyd, 1982, s.259; Makrîzî, 1991, s.370; İbn Hacer, ty, s.92; İbn Dakîki'l-Îd, 2006, s.5). Kûs kâdılığının ardından uzun süre sadece eğitim ve öğretim işleriyle ilgilenen ve diğer kâdılık tekliflerini reddeden İbn Dakîli'l-1̂d, ehil olmayan kişilerden birisinin bu göreve geleceği söylenilerek ikna edilmiş ve bunun üzerine 695 senesinde Mısır Şâfiî kâdılkudâtlı̆̆ını kabul etmiştir (İsnevî, 1987, s.102; İbn Kesîr, 1997, s.30; İbn Hacer, ty, s.93; Abdülmüteâl es-Saîdî, 1996, s.204). O, ömrünün sonuna kadar hem Şâfiî hem de Mâlikî mezhebine göre fetvâ veren ender şahsiyetlerdedir (İbn Ferhûn, 1972, s.318-9; Şevkânî, 2012, s.231).

Hüccetülislam, şeyhülislam gibi ifadelerle vasıflandırılması onun ilmî alandaki yetkinliğini bir yansıması olarak kabul edilmelidir (Zehebî, ty, s.1481; 1988, s.250; Safedî, 2000, s.137; Sübkî, 1964, s.207; Makrîzî, 1991, s.367; Kütübî, 1973, s.442).

Sübkî ve ona tabi olan Süyûtî gibi âlimler tarafından "mutlak müçtehid" olarak nitelenen İbn Dakîki'l-Îd, 11 Safer 702 (5 Ekim 1302) senesinde Cuma günü Kâhire'de vefat etmiş ve Karâfetu's-Suğrâ mezarlığına defnedilmiştir (İbn Abdülhâdî, 1996, s.266; Zehebî, ty, s.1483; Sübkî, 1964, s.207, 212; İsnevî, 1987, s.102; İbn Ferhûn, 1972, s.319; İbn Hacer, ty, s.92; Süyûtî, 1968, s.317). Yine Sübkî tarafından 7. yüzyılın müceddidi olduğu da ifade edilerek ilim dünyasındaki yeri ve önemine vurgu yapılmıştır (Abdülmüteâl es-Saîdî, 1996, s.204).

İbn Dakîki'l-Îd muhaddis, fakih, usulcü, Arap edebiyatçısı, nahiv âlimi, şâir kimliklerini taşımasına ek olarak zeki, anlayışı kuvvetli, az konuşan, vera sahibi, dindar bir müctehid olarak da bilinmektedir. Yine o, geceleri az uyuyan, mütalaası ve 
ibadeti çok olan bir kimse olarak da tanınmaktadır (İbn Abdülhâdî, 1996, s.266; Zehebî, ty, s.1482; Safedî, 2000, s.138; İbn Kesîr, 1997, s.30-1; Kütübî, 1973, s.443; İbn Hacer, ty, s.92, 95). Kaynaklar onun pek çok ilmi tahsil etmesine rağmen hadis ilmindeki mevkiinin diğerlerinden daha yüksek olduğunu belirtmişlerdir (Yâfiî, 1997, s.177; İbn Ferhûn, 1972, s.318; İbn Hacer, ty, s.92; Şevkânî, 2012, s.230; Abdülmüteâl es-Saîdî, 1996, s.204).

Kaynakların verdiği bilgiye göre o, keramet sahibi bir kimse olmakla birlikte bir tarîkata mensubiyetinden bahsedilmeyen İbn Dakîki'l-Îd, Şâfiî kâdılkudâtlığı zamanında kâdıların ipek elbise giyme âdetini kaldırması, onun dini kurallara uymadaki hassasiyetini göstermektedir (İsnevî, 1987, s.102).

Şer'î, aklî ve lügavî ilimleri cem eden müellif Hadis, F1kıh, Fıkıh usulü ve Akâidle ilgili pek çok eser yazmıştır. el-İmâm fi Ma'rifeti Ehâdîsi'l-Ahkâm, el-ìlmâm bi Ehâdîsi'l-Ahkâm, İhkâmü'l-Ahkâm Şerhu Umdeti'l-Ahkâm, el-ïktırâh fî Beyâni'l-Istılâh ve mâ Üdîfe ile Zâlike Mine'l-Ehâdîsi'l-Ma'dûde Mine's-Sihah, Şerhu'l-Erbaîne Hadisen li'n-Nevevî, Erbaûne Hadîsen Tüsâ'iyyete'l-İsnâd, Erbaûne fi'r-Rivâyeti an Rabbi'l-Âlemîn, Tabakâtü'lHuffâz, el-Emâlî,Tuhfetü'l-Lebîb fi Şerhi't-Takrîb, Allaka Şerhan alâ Muhtasarı't-Tebrizî, elImlâ, Şerhu'l-Umde fi Furûi'ş-Şâfî̀, Şerhu Uyûni'l-Mesâil fi Nusûsi's-Şâfì, Şerhu Mukaddimeti'l-Muttarizî fi Usûli'l-Fikh, Şerhu kitabi İbn Hâcib, Allaka alâ Kitâbi'l-Mahsûl, et-Teşdîd fi'r-Red alâ Gulâti't-Taklîd, Akîdetü İbn Dakîki'l-Îd, Risâletü fi Şe'ni Ehli'z-Zimme, İktinasü's-Sevânih, Dîvan, Cemû Külli Men Sumiye Bi Hâfiz, Fevâidi Hadîsi Berire bu eserler arasında yer almaktadır (İbn Abdülhâdî, 1996, s.265-6; Zehebî, ty, s.1482; Yâfiî, 1997, s.177; Safedî, 2000, s.138; Sübkî, 1964, s.212; İsnevî, 1987, s.101; İbn Rüşeyd, 1982, s.2601; İbn Ferhûn, 1972, s.318-9; Makrîzî, 1991, s.369-70; İbn Hacer, ty, s.92; Özel, 1999, 4089; Abdülmüteâl es-Saîdî, 1996, s.204; Ekinci, 2013, s.22-29; Özel, 1999: 408-9).

\section{3. Şerhu'l-Erba'in Hadîsen en-Nebeviyye isimli Eserin Kaynakları ve Hadis Şerh Metodu}

\subsection{Eser ve Kaynakları}

Tespitlerimize göre İbn Dakîki'l-Îd şerhinde çok fazla eser ismi zikretmemiş, çoğunlukla istifade ettiği muhaddis, fakih, mutasavvıf, mütekellim ve müfessir âlimlerin isimlerini vermekle iktifa etmiştir. Onun ismini zikrettiği kimseler arasında Hasan el-Basrî (ö. 110/728), Ebu'z-Zinâd (ö. 130/748), Mâlik b. Enes (ö. 179/795), Şâfiî (ö. 204/820), Abdurrahmân b. Mehdî (ö. 198/813-4), İbn Habîb es-Sülemî (ö. 238/853), muhaddis ve fakih Ahmed b. Hanbel (ö. 241/855), Buhârî (ö. 256/870), Ebû Dâvud esSicistânî (ö. 275/899), Ebû Abdullah Muhammed b. Abdüsselâm b. Sa'lebe el-Huşenî elKurtubî (ö. 286/899), İbrâhîm el-Havvâs (ö. 291/904), Taberî (ö. 310/923), Vâsitî (ö. 320/932' den sonra), Mâlik Asîlî (ö. 392/1002), Ebû Alî ed-Dekkâk (ö. 405/1015), Mâlikî İbn Battâl (ö. 449/1057), Şâfiî Beyhakî (ö. 458/1066), Ebu'l-Kâsım el-Kuşeyrî (ö. 465/1072), muhaddis Sem'ânî, Mâlikî Kâdî İyâz (ö. 544/1149), Şâfiî İbnü's-Salâh (ö. 643/1245), Mâlikî Ebu'l-Abbâs el-Kurtubî (ö. 656/1258), Şâfiî fakih Nevevî (ö. 676/1277) gibi âlimler yer almaktadır (İbn Dakîki'l-Îd, 2009, s.10, 17, 18, 20, 23, 26, 36, 43, 44, 58, $63,83,84,85,98,105,107,108)$. Yine onun garîp kelimeleri izah noktasında faydalandığı kişiler arasında Hattâbî (ö. 388/998) ile şerh ettiği eserin müellifi Nevevî bulunmaktadır 
(İbn, Dakîki'l-Îd, 2009, s.11, 32, 36). Şârih, el-İfsâh ${ }^{1}$, et-Tahrîr ${ }^{2}$ ve el-Müfhim ${ }^{3}$ gibi yararlandığı kitapların ismini nadiren zikretmiş, ancak bunların müelliflerinin adını anmamıştır. (İbn Dakîki'l-Îd, 2009, s.49, 59, 62).

Bazen âlimleri meşhur oldukları isimle değil de farklı bir şekilde zikretmesi okuyucu için zorluk teşkil etmektedir. Mesela İbn Battâl'ı, Ebû Hasan Alî b. Halef şeklinde zikretmesi bu kabilden sayılabilir (İbn Dakîki'l-Îd, 2009, s.105).

Eserin İbn Dakîki'l-Îd tarafından veya sonrasında okutulduğuna dair kaynaklarda bir bilgiye rastlanmamış olmakla birlikte yukarıda isimleri zikredilen medreselerde müderrislik vazifesini üstlenmesi vesilesiyle en azından buralarda okutulduğu söylenebilir. Yine dönemin âdeti olarak eserler yazılmak için değil, öğrencilerin istifadesine sunulmak üzere hazırlandığ 1 söylenebilir. ${ }^{4}$

\section{2. Şerh Metodu}

İbn Dakîki'l-Îd el-Erbaûn şerhine ayrı bir mukaddime yazmamış, Nevevî'nin mukaddimesi ile yetinmiştir. Giriş yazısı yazmaması münasebetiyle onun şerh metodu eser üzerinden tespit edilmeye çalışılacaktır. Yapılan çalışmada tespitimize göre müellif hadislerin dindeki yerlerine özel bir atıf yapmakla birlikte, onların doğru anlaşılmasına ve yorumlanmasına dönük olarak hadis ilminin yanı sıra Kelâm, Fıkıh ve dil ilimlerinden de istifade etmiştir.

\subsection{1. İbn Dakîkî'l-Î́d'in Şerhteki Hadisçiliği}

İbn Dakîki'l-Îd "Ameller niyetlere göredir." (Buhârî, Bedü'l-Vahy, 1; Müslim, İmâre, 155; Ebu Davud, Talâk, 11) ve "İslâm beş esas üzerine bina edilmiştir." (Buhârî, Îmân, 1, Tefsîru'l-Kur'ân, 32; Müslim, Îmân, 5) gibi bazı hadislerin önemine vurgu yaparak bunların İslâm'ın temeli, aslı, esası ve kâidesi olduğunu belirtmiştir (İbn Dakîki'l-Îd, 2009, s.10, 20, 25). Bu durum takip eden diğer hadislerin ekserisi için de geçerli olup müellif tarafından buna benzer değerlendirmelere eserde oldukça sık başvurulmaktadır. Buradan anlaşılmaktadır ki eserde yer verilen hadislerle, İslâm'ın neyin üzerine bina edildiği mevzuları izah edilmeye çalışılmaktadır.

Açıklaması yapılacak hadisin farklı tariklerini zikretmiş ve metin farklılıklarına işaret etmiştir. Mesela "Lâ ilâhe illallah, Muhammed Rasûllah demelerini sağlayıncaya, namaz kılıncaya, zekât verinceye kadar insanlarla savaşma emri aldım." (Buhârî, Îmân, 15, 28; Müslim, Îmân, 36) hadisinin Enes b. Mâlik ve Ebû Hureyre'den de rivâyet edildiği

\footnotetext{
${ }^{1}$ Ebü'l-Muzaffer Avnüddîn Yahyâ b. Muhammed b. Hübeyre eş-Şeybânî ed-Dûrî'nin dört Sünnî mezhep imamının ittifak ve ihtilâf ettiği meseleler fıkıh bablarına göre sıraladığı eseridir. Aykaç, 1999, ss.20-82-3.

2 Eserin adı et-Tahrîr fî furûi'l-fıkhi'ş-Şâfiî olup müellifi Ebu'l-Abbâs Ahmed b. Muhammed el-Cürcânî eşŞâfiî̀'dir (ö. 482).

${ }^{3}$ Eserin adı el-Müfhim li mâ eşkele min telhisi kitâbi Müslim olup müellifi Ebu'l-Abbâs el-Kurtubî'dir. Topaloğlu, 2002, ss.454-55.

${ }^{4}$ Burada, yeri gelmişken zikretmekte fayda mülahaza ettiğimiz muhakkikin bazı noktaları okumadaki hatalarına da temas edeceğiz. İlk örneğimiz şerhin metninde geçen Huşenî isimli âlimi muhakkik elMehâsinî şeklinde okumuştur (İbn Dakîki'l-Îd, 2009, s.83). ${ }^{4}$ Yine et-Tahrîr isimli eseri hata ile et-Tecrîd şeklinde kaydetmiştir (İbn Dakîki'1-Îd, 2009, s.62). ${ }^{4}$ Gerçi bu hataların müstensihlerden kaynaklanabileceği ihtimali de göz önünde bulundurulmalıdır.
} 
belirtip metin farklılıklarını göstermiş ve şerhinde bunlardan istifade etmiştir (İbn Dakîki'l-Îd, 2009, s.35). Şârih yine bu hadisi Hz. Ebû Bekr'in halifeliği döneminde kendisine zekât vermeyenlerle mücadele edeceğine dair delil olarak kullandı̆̆ de paylaşmıştır (İbn Dakîki'l-Îd, 2009, s.36). ${ }^{5}$

Müellif, kadere iman etmenin gerekliliği belirttikten sonra "Oysaki sizi ve yapmakta olduklarınızı Allah yarattı." (Saffât, 96) ve "Şüphesiz Biz her şeyi bir ölçüye göre yaratmışızdır." (Kamer, 49) âyetlerini zikrederek kaderin olduğuna delil olarak onları zikretmiştir (İbn Dakîki'l-Îd, 2009, s.15). İbn Dakîki'l-îd, "Kim Allah'a ve âhiret gününe inanıyorsa ya hayır söylesin ya da sussun." (Buhârî, Edeb, 31, 85; Müslim, Îmân, 74, Lukata, 14) hadisinin çerçevesinde hareket edebilmenin en önemli göstergesinin uzuvlarını kontrol altına alınmasını göstermiş ve bu konuya "Bilmediğin şeyin ardına düşme; doğrusu kulak, göz ve kalp, bunların hepsi o şeyden sorumlu olur." (İsra, 17/36) ve "İnsan hiçbir söz söylemez ki onun yanında (yaptıklarını) gözetleyen (ve kaydeden) hazır bir melek bulunmasın." (Kâf, 18) âyetlerini delil olarak getirmiştir (İbn Dakîki'l-Îdd, 2009, s.48). Yine kötülügü gidermek için iyiliğin yapılması ögütleyen hadisin (Tirmizî, el-Birr ve's-Sıla, 55; Dârimî, Rikâk, 74) izahında müellif, “Çünkü iyilikler kötülükleri giderir. (Hûd, 114) âyetini delil olarak kullanmıştır."6

Şârih kadere iman etmekle ilgili olarak diğer bir hadisle de istişhâdda bulunmuştur. Örneğin “Bil ki! Ĕğer bütün ümmet sana fayda vermek için toplansa, Allah'ın senin için yazdiğından başka sana fayda veremez. Ve eğer bütün ümmet sana zarar vermek için toplansa, Allah'ın senin için yazdığından başka sana zarar veremez. Kalemler kaldırlld ve sayfalar kurudu." hadisine bu minvalde yer vermiştir (İbn Dakîki'l-Îd, 2009, s.15). Yine kişiye şüphesiz gelenlere sarılmasının emredildiği hadisi (Buhârî, Büyû', 3; Tirmizî, Sıfâtu'l-Kıyâme, 60; Nesâ̂i, Eşribe, 52), "Helal da bellidir, haramda bellidir. İkisi arasında helale de, harama da benzeyen ve insanlarm çoğunun hükmünü bilmediği şeyler vardır." (Buhârî, Îmân, 37; Müslim, Müsâkât, 20) ile "Kul, haram olabilecek şeye düşmekten uzak durarak sakıncalı olmayan şeyi bile terk etmedikçe takvalı kişilerden olmak durumuna yükselemez." (Tirmizî, Zühd, 40) hadisleriyle izah etmiştir (İbn Dakîki'1-Îd, 2009, s.43).7

İbn Dakîki'l-Îd âyet ve hadis yanında sahâbe kavli ile de istişhâdda bulunmuştur. Hz. Peygamber kendisine soru soran bir kimseye iman edip dosdoğru olmasını ögü̈llemiştir. Şarih bu konuyu "Şüphesiz "Rabbimiz Allah'tır" deyip de sonra dosdoğru olanlar var ya, onların üzerine akın akın melekler iner ve derler ki: “Korkmayın, üzülmeyin, size (dünyada iken) vaat edilmekte olan cennetle sevinin!" (Fussilet, 30) âyetiyle beraber Hz. Ömer'in “Dosdoğru ve Allah'a itaat üzerine olun. Tilkinin yoldan saptığı gibi sapmayın." sözü ile de konuyu açıklamıştır (İbn Dakîki'lÎd, 2009, s.58).

Âyet ve hadislere ek olarak çeşitli kişilerin sözlerinden de yararlanarak hadisleri açıklamıştır. Mesela "Kişinin kendisini ilgilendirmeyen şeylerden yüz çevirmesi onun güzel ahlakındandır." (Tirmizî, Zühd, 11; İbn Mâce, Fiten, 13) hadisini Lokmân (a.s)

\footnotetext{
${ }^{5}$ Benzer örnekler bkz. İbn Dakîki'1-Îd, 2009, s.44, 46.

${ }^{6}$ Diğer örnekler için bkz. İbn Dakîki'l-Îd, 2009, s.50.

${ }^{7}$ Diğer örnekler için bkz. İbn Dakîki'l-Îd, 2009, s.48, 50.
} 
ve Hasan el-Basrî'nin sözleriyle açılamıştır. Lokmân (a.s)'a kendisine verilen faziletlerin, doğru sözlü olmak, emanete riayet göstermek ve kendisini ilgilendirmeyen şeyleri terk etmek olduğunu ifade etmesi ile Hasan el-Basrî de kişinin kendisini ilgilendirmeyen konularla meşguliyetinin Allah'ın ondan yüz çevirmesi olarak değerlendirmesi müellife göre hadisin dindeki önemini göstermesi bakımından önemlidir (İbn Dakîki'1-Îd, 2009, s.43).

$\mathrm{O}$, hadislerden çıarımda bulunmuştur. Şöyle ki, kıyamet alametlerinden kabul edilen yüksek ev yapılmasının ihtiyaç olmadığında bu durumun mekruh olduğunu ifade etmiştir. (İbn Dakîki'l-Îd, 2009, s.16).

Hadisin metnindeki hatayı tespit etmiş ve bunu izah etmiştir. Örneğin İslâm'ın beş temeli olduğu zikredilen hadiste bazı kimselerin haccı orucun üzerine takdim ettiğini, bunun ise vehim olduğu zikrederek bu kimseleri tenkit etmiştir. Nitekim Abdullah b. Ömer'e hadis nakledildiğinde haccı takdim eden kimseyi tenkit etmiş ve bunu yapmasını yasaklamıştır (İbn Dakîki'l-Îd, 2009, s.20). Nevevî el-Erbaûn isimli eserinde "Herkese iddialarn üzerine diledikleri verilmiş olsa çoğu kimse başkalarının kimselerin mallarını, canlarını iddiâ eder dururlar. Lâkin delil getirmek iddia edene, yemin de inkâr edene düşer." (Buhârî, Rehn, 6, Tefsîru'l-Kur'ân, 60; Müslim, Akziye, 1) hadisinin Buhârî ve Müslim tarafından Abdullah b. Abbâs tarikiyle rivâyet edildiğini söylemiştir. Asîlî ise buna itiraz ederek hadisin merfû olmadığını, sözün İbn Abbâs'a ait olduğunu iddia etmiştir. Müellif bu duruma itiraz ederek Buhârî ve Müslim'in şehadetlerini yeterli görmüş, hadiste herhangi bir teâruz ve ızdırâb bulunmadığını bildirmiştir (İbn Dakîki'l-1̂d, 2009, s.85).

Hadis şerhinde İbn Dakîki'l-Îd, hadiste mübhem bırakılan kişi adlarına açıklık getirmiştir. Mesela "Sizi men ettiğim şeylerden çekinin. Emrettiğimi de gücünüz yettiğince yapın. Şüphesiz sizden öncekileri, çok soru sormalarn ve peygamberlerine muhalefet etmeleri mahvetmiştir." (Buhârî, İ'tisâm, 2; Müslim, Fezâil, 130) hadisinin siyakında Hz. Peygamber insanlara hac etmelerini emretmiştir. Bunun üzerine Akra' b. Hâbis her sene mi olacağını Rasûllulah yukarıdaki sözleri sarf etmiştir. Hadisin metninde soru soran kimseye dair bir açılama bulunmamaktadır (İbn Dakîki'l-Îd, 2009, s.38).

İbn Dakîki'l-1̂d hadislerin anlaşılmasına yönelik olarak hadislerin sebeb-i vürûduna temas etmiştir. "Nerede olursan ol, Allah'tan kork. Kötülüğ̈̈̈n peşinden iyilik yap ki onu yok etsim. Insanlara da güzel ahlakla muâmelede bulun." (Tirmizî, el-Birr Ve's-Sıla, 55; Dârimî, Rikâk, 74) buyuran Hz. Peygamber bu sözlerini yöneticiliği çokça arzulayan Ebû Zerr Cündeb b. Cünâde'ye söyleyerek onun tabiatının yöneticiliğe yatkın olmadığını ifade etmiştir (İbn Dakîki'l-Îd, 2009, s.53).

Her türlü açıklama ve izahı yaptıktan sonra durumu "Allahu a'lem" diyerek noktalaması ince bir anlayışın tezahürüdür (İbn Dakîki'l-Îd, 2009, s.42, 46).

Bahis konusu eser klasik bir şerh çalışması gibi olmadığından klasik bir şerhte beklenen özellikler eserde yer almamaktadır. Mesela her bir hadis incelenirken tüm senedde geçen râvîleri inceleyip hakkında bilgi sunmak, hadisten hüküm çıkarmak, râvî tasarruflarını tespit etmeye çalışmak, metinlerin içerik tahlilini yapmak, tüm metni 
gramer yönünden incelenmek gibi konularda çok fazla bilgi vermemektedir. Müellif, çalışmasında, hadisin doğru anlaşılmasına yönelik olarak yukarıda zikredilen mevzular da dâhil olmak üzere gerektiğinde konu ile ilgili yeteri kadar bilgi vermekle iktifâ etmiştir. Bu çalışmanın eksik bir yönü olmakla birlikte okuyucu için bir avantaj oluşturmaktadır.

\subsection{2. Şerhin Kelâmî Yönü}

İbn Dakîki'l-Îd hakkında kaynaklar itikadî mezhep açısından Eş'arî veya Mâturîdî olduğuna dair bir bilgi zikretmemişlerdir. Öte yandan o, şerhte bazı hadislerde Kelâm ilmiyle ilgili açılamalarda bulunmuştur. Mesela Cebrâîl'in Hz. Peygamber'e gelerek iman, İslâm, ihsân ve kıyâmet hakkında sorular sorduğu hadisle (Müslim, Îmân, 1; Ebû Dâvud, Sünnet, 17; Nesâî, Îmân, 6) ilgili açıklama yapan şârih, iman ve İslâm'ın dil ve din noktasında farklı hakikatler olduğunu, ancak bunların birbirlerinin yerine kullanılabileceğini belirterek Ehl-i sünnet'in görüşleri çerçevesinde hareket etmiştir (İbn Dakîki'l-Îd, 2009, s.14, 19).

Şârih, yukarıdaki hadiste Hz. Peygamber'in teferruatına girmediği Allah'a, meleklere, peygamberlere, kiyamet gününe ve kadere imanın ne olduğunu kisaca izah etmiştir. Mesela o, Allah'a imandan maksadın onun kemâl ve celâl sıfatlarıyla mevsuf, noksanlıklardan ise münezzeh olduğunu söyleyip tasdik etmektir, şeklinde açılamıştır. Yine onun, ölümden sonra dirilişin, hesap vermenin, mîzanın, sıratın, cennet ve cehennemin olduğuna inanmanın da kıyamet gününe imanın içinde zikretmesi önemlidir. Tüm bu hususlara iman etmenin hem selef hem de halef imamların mezhebi olduğunu ifade etmesi konunun haiz olduğu önemdendir (İbn Dakîki'l-Îd, 2009, s.15).

Müellif akide konuları arasında yer alan imanın artması veya azalması ile ilgili âlimlerin görüşlerini zikretmiş, Hz. Ebû Bekr'in imanın diğer inananlardan üstün olduğunu söyleyerek imanın arttığını veya azaldığını ifade etmek istemiştir. Onun bu konudaki fikri, Eş'ârî mezhebinin görüşüyle uyuşmaktadır (İbn Dakîki'l-Îd, 2009, s.178; Gölcük ve Toprak, 2001, s.126).

Şârih, İslâm'ın beş esas üzerine bina edildiğine dair hadisin şerhinde (Buhârî, Îmân, 1, Tefsîru'l-Kur'ân, 32; Müslim, Îmân, 5), bu hadiste zikredilen beş hususun devamlı olarak farz, cihadın ise belirli zaman dilimlerinde olduğunu söylemiştir (İbn Dakîki'l-Îd, 2009, s.20).

İbn Dakîki'l-Îd insanın yaratılış evrelerinden bahsedilen hadisin devamında $\mathrm{Hz}$. Peygamber'in “Kendinden başka ilâh olmayan Allah'a yemin ederim ki, sizden bir kimse cennet ehlinin amelini işler, o kadar ki kendisi ile cennet arasında sadece bir arşın mesafe kalır. Ancak hakkındaki yazı üstün gelir, cehennem ehlinin amelini işlemeye başlar ve cehenneme girer. Yine bir kimse cehennem ehlinin amelini yapa yapa, kendisi ile cehennem arasinda sadece bir arşın mesafe kalır. Fakat hakkındaki yazı ona üstün gelir, cennet ehlinin amellerini işlemeye başlar ve cennete girer." sözlerini (Buhârî, Bed'u'1-Halk, 6, Ehâdîsu'l-Enbiyâ, 1, Kader, 1) kaderin isbatı olarak zikretmiş ve Ehl-i Sünnet âlimlerinin de aynı kanaatte olduklarını ifade etmiştir (İbn Dakîki'l-Îd, 2009, s.23). Yine bu hadisin şerhinde hayırdan şerre 
yönelen kimselerin nadir; şerden hayra yönelenlerin ise oldukça çok olduğunu zikretmiş ve bu görüşüne "Rahmetim gazabımı geçti." (Buhârî, Tevhîd, 15, 22, 28, 55, Bed'u'l-Halk, 1; ) hadisini delil olarak ileri sürmüştür (İbn Dakîki'1-Îd, 2009, s.23). Yine bu hadis kapsamında kişilerin, 'nasıl olsa kaderimiz belli' diyerek şeriatta varit olan ameller ve sorumlulukların yerine getirilmesinden imtina etmemeleri gerektiğini, iyi kişilerin Allah tarafından güzel amellere yönlendirileceği gibi şakî kimselere de kötülük yollarının kolaylaştırılacağını ifade edip "en güzel söz olan Allah'ın birliğini doğrulayanın işlerini kolaylaştırırız." (Leyl, 7) mealindeki âyeti ile "Biz de onu en zora hazırlarız." (Leyl, 10) âyetini konuya delil olarak getirmiştir (İbn Dakîki'1-Îd, 2009, s.24).

"Lâ ilâhe illallah, Muhammed Rasûllah demelerini să̆layıncaya, namaz kılıncaya, zekât verinceye kadar insanlarla savaşma emri aldım." (Buhârî, Îmân, 15, 28; Müslim, Îmân, 36) hadisinde geçen bu kimselerin kim olduğuna dair açılamada bulunan İbn Dakîki'l-Îd, Hattâbî'den naklen onların Ehl-i Kitâb dışındaki putperest, müşrik Arap ve iman etmeyen kimseler olduğunu zikretmiştir. Yine bu hadis kapsamında zâhiren Müslüman görünen ancak küfrünü gizleyen kimseler hakkında cumhur ulemânın onların Müslüman sayılacağı kanaatinde olduklarını ifade etmiştir. Bu hadisin farklı bir tarikinde ise Hz. Peygamber "Lâ ilâhe illallah deyinceye ve benim getirdiklerimin hepsine iman edinceye kadar savaşacağım." (Müslim, Îmân, 34;Dârekutnî, 2004, s. 467) buyurmuştur. Bu noktadan hareket eden şârih bu hadisin, mutlak olarak İslâm'ı kabul eden bir kimse için Hz. Peygamber'in getirdiklerine iman etmesinde bir tereddüd bulunmadığı, bunun o kişi için delil olarak yeterli olduğu ve bu konuda mütekellimlerin delillerini de bilmesinin gerekmediği noktasında âlimlerinin çoğunluğu için açık bir delil teşkil ettiğini zikretmiştir (İbn Dakîki'l-Îd, 2009, s.37).

\subsection{3. Şerhin Frkhî Yönü}

Hz. Peygamberin insanlara hac etmelerini emretmesi (Buhârî, I'tisâm, 2; Müslim, Fezâil, 130) üzerine Akra' b. Hâbis her sene mi yapılacağını sormuştur. Buradan hareketle usulcüler emrin tekrar edilip edilmesini tartışmışlar, bir kısmı tekrara gerek olmadığını söylerken diğer bir kısmı ise gerekli görmüştür. İbn Dakîki'lÎd de emrin tekrarını gerekli görmemiştir. O, bu hadisin Hz. Peygamber'in ahkâm konusunda içtihat ettiği ve bu hususta vahyin de şart olarak ileri sürülemeyeceği noktasında Ehl-i sünnet mezhepleri için delil niteliği taşıdığına dikkat çekmiştir. (İbn Dakîki'l-Îd, 2009, s.38-9).

Müellif üç kişinin kanının helal olduğunun belirtildiği hadiste (Buhârî, Diyât, 7; Müslim, Kasâme, 6) zikredilen Müslüman cemaatinden ayrılarak dininden dönen kimsenin İslâm'a tekrar dönmesi durumu müstesna öldürüleceğini belirtmiştir. $O$, aynı durumun bir bid'at ve bağy vesilesi ile gerçekleşmesinin de aynı kapsamda değerlendirileceğini zikretmiştir. Yine namaz kılmayan kimsenin katli meselesinde bu hadisi delil olarak kullananların olduğunu ancak konunun tartışmalı bir yönünün bulunduğunu belirterek tarafların konu ile ilgili görüş ve delillerine yer vermiştir (İbn Dakîki'l-Îd, 2009, s.46-7). İbn Dakîki'l-Îd evli olduğu halde zina yapan kimselerin cezasının recm olduğu konusunda ulemânın ittifak ettiğini belirtmiştir. Yine aynı 
hadisin şerhinde hür kimsenin köleye karşılık öldürülemeyeceği hakkında Şâfiî, Mâlik b. Enes ve Ahmed b. Hanbel'in aynı fikirde olduğuna dikkat çekmiş, bu konuda cumhurun aksine Hanefî mezhebinin bu hadisle istidlal ederek köleye karşı hür bir kimsenin öldürüleceğini belirterek onları tenkit etmiştir (İbn Dakîki'l-Îd, 2009, s.47).

Şârih kıyâsü'l-aks'inn (Çaldak, 2008, s.183-184) delil olarak kullanılabileceğine dair "Ya Resûla'llâh!, Şehevî arzumuzu yerine getirmekte de sevap olur mu? Dediler. Hz. Peygamber Şöyle cevap verdi. Ne dersiniz? Bu arzuyu haram yoldan giderseniz, size günah olur mu? İşte arzunuzu helâl yoldan giderdiğiniz takdirde, sizin için sevap ve mükâfat vardır." (Buhârî, Sulh, 11, Cihâd, 70; Müslim, Salâtu'l-Müsâfirîn, 84, Zekât, 56) hadisini zikretmiştir. Her ne kadar konu usulcüler arasında tartışmalı olsa da İbn Dakîki'l-Îd bu hadis nokta-yı nazarından onun kullanılabileceğini ifade etmiştir (İbn Dakîki'l-Îd, 2009, s.70).

Nevâzi1 ${ }^{9}$ konularında soru sormayı Selef ulemâsının câiz görmediğini, ancak zamanın ilerlemesiyle birlikte ilmin kaybolmamasının önüne geçmek maksadıyla onların yazıldıklarını ifade eden İbn Dakîk'l-Îd, Hanefî mezhebi hariç diğer üç mezhebe göre bunların gerçekleşmesinden önceki hükümleri noktasında ulemânın ihtilaf ettiklerini belirtip konunun ayrıntıları için okuyucuyu Fıkıh kitaplarına yönlendirmiştir (İbn Dakîki'l-1̂ld, 2009, s.80).

Müellif helal ve haramin belli olduğunu (Buhârî, Îmân, 37; Müslim, Müsâkât, 20) ifade eden hadisin daha net anlaşılması maksadıyla helal ve haramların neler olduğuna yönelik ilgili âyetlerin bir kısmını zikretmiştir. Örneğin "Bu gün size temiz ve hoş şeyler helâl kılındı. Kendilerine kitap verilenlerin yiyecekleri size helâl, sizin yiyecekleriniz de onlara helâldir." (Mâide, 5), "(Savaş esiri olarak) sahip olduklarını hariç, evli kadınlar (da size) haram kılındı. (Bunlar) üzerinize Allah'ın emri olarak yazılmıştır. Bunların dışında kalanlar ise, iffetli yaşamak ve zina etmemek şartıyla mallarınızla (mehirlerini verip) istemeniz size helâl kılındı." (Nisâ, 24)ve "Sizin için de yolcular için de bir geçimlik olmak üzere deniz avı yapmak ve deniz ürünlerini yemek sizlere helâl kılındı. Kara avo ise ihramlı olduğunuz sürece size haram kılındı." (Mâide, 96) âyetleri zikredilebilir (İbn Dakîki'l-Îd, 2009, s.27-8).

\subsection{4. Şerhin Lügavî Yönü}

Şârih, hadisteki bazı kelimelerin izahını yapmıştır. Dinin nasihat (Müslim, Îmân, 95; Ebû Dâvud, Edeb, 67) olduğu belirtilen hadisteki "nasihat" kelimesinin açılamasında Hattâbî'den nakilde bulunarak Allah'a nasihatin/samimiyetin, O'na iman etme, şirki reddetme, O'nun sıfatlarını reddetmeme, O'nun tüm kemâl ve celâl sıfatları taşıdığı, O'na itaat etme, O'na isyandan kaçınma, O'nun için sevme veya buğz etme, O'nu inkâr edenlerle mücadele, O'nun nimetlerine şükür etme, tüm işlerde ihlaslı hareket etme gibi manalara geldiğini söylemiştir (İbn Dakîki'l-Îd, 2009, s.32). Yine "Tayyib" kelimesinin Allah'ın sıfatı olarak kullanıldığında noksanlıklardan münezzeh olduğu manasına geldiğini ifade etmiştir (İbn Dakîki'l-Îd, 2009, s.41). Yine o

\footnotetext{
8 İlletin bulunmaması sebebiyle asl için sabit olan hükmü fer'den nefyetmektir. Neşşâr, 1984, s. 125.

${ }^{9}$ Mezhep imamlarından sonar ortaya çıkmış fıkhî meseleler için kullanılan bir terimdir. Kaya, 2007, ss. 345.
} 
“İstikâmet” kelimesini Ebu'l-Kâsım el-Kuşeyrî’nin (ö. 465/1072) şu şekilde tanımladığını nakletmiştir: "İstikâmet, işlerin kendisiyle kemâle erdiği ve tamamlandığı, istikamet sahibi olunmasıyla hayırların meydana geldiği ve düzenin sağlandığı, O'nun bulunmaması halinde ise işi gerçekleştirmek için harcanacak gayretin ve özenin heba olacağıdır. Yine o, haslet ve sabır kelimelerinin tarifinde Vâsitî (ö. 320/932' den sonra) ve Ebû Alî el-Dekkâk'tan (ö. 405/1015) istifade etmiştir (Kuşeyrî, 1989, s. 356; İbn Dakîki'1-Îd, 2009, s.58)"'10.

Müellif gerektiği yerlerde hadislerin i'rabını yapmıştır. Mesela "ثَفَقِّ أَوْ سَعِيد" ibaresindeki kelimelerin mahzuf mübtedanın haberi olduklarını ve mübtedanın takdiren "هُوَّو zamiri olduğunu ifade etmiştir (İbn Dakîki'l-Îld, 2009, s.23).

Bazı kelimelerin zabtına dair bilgi verdikten sonra hangi okuyuş tarzının daha doğru olduğunu zikretmiştir. Mesela "Sana şüpheli olanı bırakıp şüphesiz olanı al." (Buhârî, Büyû', 3; Tirmizî, Sifâtu'l-Kıyâme, 60; Nesâî, Eşribe, 52) hadisinde geçen

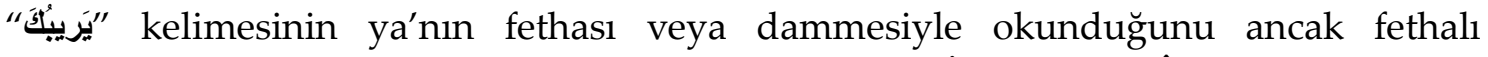
okuyuşun daha fasih ve meşhur olduğunu belirtmiştir (İbn Dakîki'l-Îd, 2009, s.42). ${ }^{11}$

Şârih aynı zamanda bazı kelimeleri sarf noktasından da incelemiştir. Mesela "Ey Kullarım! Ben zulmü kendime haram saydım. Sizin de aranızda onu haram kıldım. Öyleyse zulmetmeyin." (Müslim, el-Birr ve's-Sıla, 55) kutsî hadisinde geçen "تَظَالَمُوائو lafzının aslının "تَظَّالَمُوا" olduğunu ancak tahfif yapılarak ilk geçtiği şekilde okunduğunu belirtmiştir. (İbn Dakîki'1-Îd, 2009, s.65). ${ }^{12}$

Müellif kelimelerin yanlış anlaşılmasını önlemek amacıyla çoğul kelimelerin

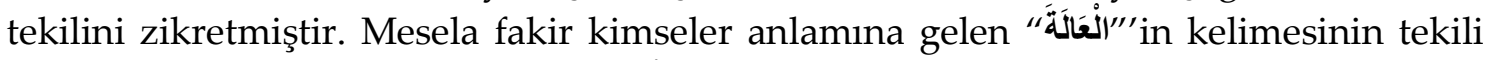
olan “عَائلِّل"i zikretmiştir (İbn Dakîki'l-Îd, 2009, s.16).

İbn Dakîki'l-Îd hadislerin metninde geçen kelimelerin zabtı ile ilgili bilgi vermiştir. Örneğin kıyamet alâmetlerini ifade eden " kelimesinde yer alan elif harfinin hemze ile okunduğunu belirtip eşanlamlısının ise "alamet" kelimesi olduğunu ifade ederek anlaşılmasını kolaylaştırmıştır (İbn Dakîki'l-Îd, 2009, s.16). Yine o "الأَمَّة "

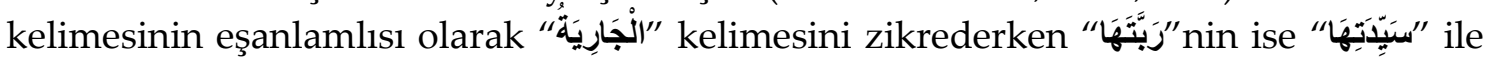
karşılandığını söylemiştir (İbn Dakîki'1-Îd, 2009, s.16).13

Hadisin metninde geçen kelimelerin açıklanmasında dil âlimlerinden istifade

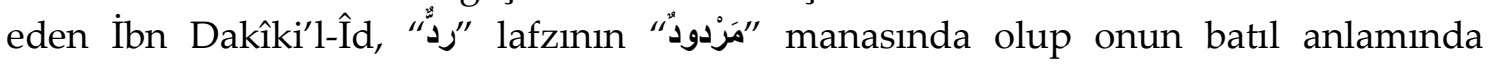
kullanıldığı ifade etmiştir (İbn Dakîki'l-Îd, 2009, s.25). Yine "Zarar verme de yoktur,

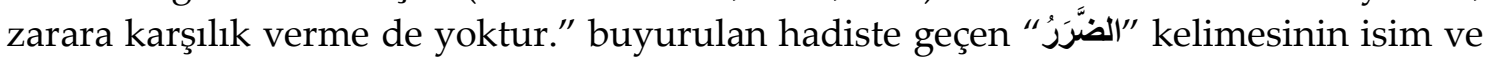
“الضِّرَارُ In ise fiil olduğuna İbn Habîb'ten nakilde bulunarak açılklk getiren şârih, kimi ulemâ tarafından bunların aynı manaya geldiğini de ifade etmiştir. (İbn Dakîki'l-Îld, 2009, s.83).

\section{Sonuç}

\footnotetext{
${ }^{10}$ Diğer örnekler için bkz. İbn Dakîki'1-Îd, 2009, s.33-4, 47, 58, 63, 71, 79.

${ }^{11}$ Diğer örnekler için bkz. İbn Dakîki'l-Îd, 2009, s.51-2, 62.

${ }^{12}$ Diğer örnekler için bkz. İbn Dakîki'l-Îd, 2009, 69.

${ }^{13}$ Diğer örnekler için bkz. İbn Dakîki'l-Îd, 2009, s.42.
} 
İbn Dakîki'l-Îd, ilmî bir aile ortamında yetişmesinden dolayı erken yaşlarda ilimle meşgul olmuş ve kendini özellikle Şâfiî ve Mâlikî fıkhında yetiştirmiş önemli bir Hadis ve Fıkıh âlimidir. Bu durum ahkâm hadislerine yönelik olarak kaleme aldığı elİmâm, el-İlmâm ve İhkâmu'l-ahkâm isimli eserlerinden anlaşılmaktadır.

$\mathrm{Bu}$ eserlerinin yanında Nevevî'nin el-Erbaûn'unda geçen hadislerin anlaşılmasında ve yorumlanmasında ihtiyaç duyulan yerleri açıklayan İbn Dakîki'l-Îd, şerhte esas aldığı üç eser hariç diğer eserlerin adlarını anmamış, sadece yararlandığı âlimlerin isimlerini zikretmekle yetinmiştir. Şerhte dikkat çeken taraflardan biri de hadis ilmi yanında Fıkıh, Kelâm ve dile dönük açılamaların bulunmasıdır. Bu açılamalarında Kelâm noktasında Ehl-i sünnet tarafında yer almış ve onların görüşleriyle amel etmiştir. Onun şerhte açık bir şekilde muhalif bir mezhebi eleştirdiği tespit edilememiştir. Fıkıh ilmi çerçevesinde ise hadisçilerin mezhepleri olan Şâfiî, Hanbelî ve Mâlikî mezhebinin görüşleri içerisinde hareket etmiş, Hanefîlere ise tenkitler yöneltmiştir. Kaynak ismi olarak zikrettiği eserlerden biri Hanbelî İbn Hübeyre (ö. 560/1165), Mâlikî Ebu'l-Abbâs el-Kurtubî (ö. 656/1258), diğeri ise Şâfiî Ebu'l-Abbâs el-Cürcânî (ö. 482/1089) olması kanaatimizi desteklemektedir. Yine onun istifade ettiği âlimleri de incelediğimizde aynı durum söz konusu olup aralarında Hanefî mezhebine mensup kişilerin olmadığı görülmektedir. Kelâmî ve fikhî izahların yanında lügavî açıklamalarda bulunarak hadislerin anlaşılmasına önemli katkılar sağlamıştır. Hadislerin şerhinde özellikle âyet ve hadislerin birbirlerinin tamamlayıcı unsurları olmasından dolayı bunlardan oldukça istifade etmiştir. Şerhte takip ettiği usullerden birisi de hadisin metninde yer alan garip kelimeleri izah etmesidir. Ayrica bazı hadislerin vürûd sebebini zikrederek hadislerin doğru anlaşılmasına katkı sağlamıştır. Şerhin dikkat çeken diğer bir yönü ise bazı kelimelerin tekillerini, çoğullarını ve eş anlamlılarını vermesi, sarf ilmiyle ilgili bilgiler zikretmesi yanında kimi cümlelerin irabını yapmasıdır. Ayrıca bazı kelimelerin tanımında İbrâhîm elHavvâs (ö. 291/904), Vâsitî (ö. 320/932'den sonra), Ebû Alî ed-Dekkâk (ö. 405/1015) ve Ebu'l-Kâsım el-Kuşeyrî (ö. 465/1072) önemli mutasavvıflardan yararlanması ise şerhin dikkat çekici diğer bir yönüdür.

Müellif şerhte geçmeden önce ilgili hadisin kaynak eserlerde geçtiği yeri belirtmiş, "dinin esası, dinin direği dinin temelidir" gibi ifadeler zikrederek hadisin önemini vurgulamış ve konuyu izah ederken ilim adamlarından nakilde bulunmuş, kimi hadisin senediyle ilgili açıklamaları vermiş, farklı tariklerini zikretmiş, hadisteki hatayı tespit etmiş, senette mübhem olan kişinin ismini tespit etmiş, Arapça ilgili bilgiler vermiş, metinde geçen kelimeleri zabt altına almış, hadisin nasıl anlaşılması gerektiğini izah etmiştir. Hadisi şerh ederken ise tüm hadisi şerh etmemiş, açıklamak istediği kısmı parantez içerisine alarak gerekli izahları yapmıştır. Hadisin izahında âyetle ve hadisin yanında, sahâbe kavliyle veya âlimlerin sözleri ile istişhâddan yararlanmiştır. 


\section{Kaynakça}

Abdülmüteâl es-Saîdî. (1996). el-Müceddidûn fi'l-İslâm mine'l-karni'l-evvel ile'r-râbi' aşer. Kâhire.

Aydınlı, A. (2009). Hadis Istılahları Sözlü̆ğ̈̈. İstanbul.

Aykaç, M. (1999). Ebü'l-Muzaffer İbn Hübeyre. Diyanet İslam ansiklopedisi içinde. (C.20, ss.82-3). Ankara.

Buhârî, Ebû Abdullah Muhammed b. İsmâîl. (2002). Sahîhu'l-Buhârî. Dımaşk.

Çakan, İ. L. (2016). Hadis Edebiyatı. İstanbul.

Çaldak, H. (2008). İslam Dünyasında Kullanılan Çıkarım Yöntemleri Ve Mantıki Yöntemlerle İlişkisi. Ekev akademi Dergisi, 37, 183-184.

Dârekutnî, Alî b. Amr el-Bağdâdî. (2004). es-Sünen. Şauyb el-Arnaût ve Diğerler (thk.) (C. 2). Beyrût.

Dârimî, Abdullah b. Abdurrahmân es-Semerkandî. (1966). es-Sünen. Fevvâz Ahmed Zemerlî Hâlid Sebi' el-Alemî (thk). Beyrût.

Ebû Dâvud, Süleymân b. Eş‘as es-Sicistânî. (1998). es-Sünen. Muhammed Avvâme (thk). Beyrût.

Efendioğlu, Mehmet. (2010). Şerh. Diyanet İslam ansiklopedisi içinde. (C.38, ss.559-60). Ankara.

Ekinci, A. (2013). İbn Dakîki'l-Îd ve İhkâmu'l-Ahkâm fî Şerhi Umdeti'l-Ahkâm Adlı Eserinin İslam Fıkhındaki Yeri. (Yayımlanmamış Yüksek Tezi). Necmettin Erbakan Üniversitesi Sosyal Bilimler Enstitüsü, Konya.

Gölcük, Ş. Toprak, S. (2001). Kelam, Konya.

İbn Abdilber en-Nemerî, Yûsuf b. Abdullah b. Muhammed el-Kurtubî. (1993). el-İstizkâr. Abdülmu'tî Emîn Kal'acî (thk). (C.22). Beyrût.

İbn Abdilber en-Nemerî, Yûsuf b. Abdullah b. Muhammed el-Kurtubî. (1989). et-Temhîd li mâ fi'l-Muvatta mine'l-meânî ve'l-esânîd. Saîd Ahmed A'rab (thk). (C.20). Titvân.

İbn Abdülhâdî, Ebû Abdullah Muhammed ed-Dımaşkî. (1996). Tabakâtu'l-Ulemâi'l-Hadîs. Ekrem el-Bûşî-İbrâhîm ez-Zeybek. (thk). (C.4). Beyrut.

İbn Dakîki'l-Îd, Takiyyüddîn Alî b. Vehb el-Kureşî. (1987). İhkâmu'l-ahkâm fî şerhi Umdeti'lAhkâm. Ahmed Muhammed Şâkir (thk). (C.1). Beyrût.

İbn Dakîki'l-Îd, Takiyyüddîn Alî b. Vehb el-Kureşî. (2006). el-iktirâh fí Beyâni'l-Istılâh. Beyrût.

İbn Dakîki'l-Îd, Takiyyüddîn Alî b. Vehb el-Kureşî. (2013). el-illmâm bi ehâdîsi'l-ahkâm. Muhammed Hallûf el-Abdullah (thk). (C.1). Dımaşk.

İbn Ferhûn, Ebü'l-Vefa Burhaneddin İbrâhim b. Ali b. Muhammed. (1972). ed-Dîbâcu'l-müzheb fî ma'rifeti a'yan ulemâ'i'l-mezheb. Muhammed el-Ahmedî Ebü'n-Nur (thk). (C.2). Kâhire.

İbn Hacer, Ahmed b. Alî b. Muhammed el-Askalânî. (ty.). ed-Dürerü'l-kâmine fí a'yâni'l-miete'ssâmine. (C.4). Beyrût.

İbn Kesîr, Ebu'l-Fidâ İmâduddîn İsmâîl b. Ömer. (1997). el-Bidâye ve'n-nihâye. Abdullah Abdulmuhsin et-Türkî (thk). (C.18). Cîze. 
İbn Manzûr, Muhammed b. Mükerrem b. Alî b. Ahmed el-Ensârî. (ty.). Lisânu'l-Arab. (C.4). Beyrût.

İbn Mâce, Ebû Abdullah Muhammed b. Yezîd el-Kazvînî. (1975). es-Sünen. Muhammed Fuâd Abdülbâkî (thk). Kâhire.

İbn Rüşeyd, Ebû Abdullah Muhibbüddîn Muhammed b. Ömer. (1982). Mil'ü'l-aybe bi ma cumia bi tûli'l-gaybe fi'l-vicheti'l-veche ile'l-harameyn Mekke ve Taybe. Muhammed elHabîb İbnü'l-Hoca (thk). (C.3). Beyrût.

İsnevî, Abdürrahîm. (1987). Tabakâtu'ş-Şâfiiyye. Kemâl Yûsuf el-Hût (thk). (C.2). Beyrût.

İsyûbî, Muhammed b. Alî b. Âdem el-Vellevî. (2003). Zehîratü'l-ukbâ fî şerhi'l-Müctebâ. (C.21). Mekke.

Karacabey, S. (1990). Hattâbî'nin Hadis İlmindeki Yeri ve Şerh Metodu. (Yayınlanmamış doktora tezi). Uludağ Üniversitesi Sosyal Bilimler Enstitüsü, Bursa.

Kaya, Eyyüp Said. (2007). Nevâzil. Diyanet İslam Ansiklopedisi içinde. (C.33, ss.34-5). Ankara.

Kuşeyrî, Ebü'l-Kāsım Zeynülislâm Abdülkerîm b. Hevâzin b. Abdilmelik. (1989). er-Risâletu'lKuşeyriyye. Mahmûd b. Şerîf (thk.). Kâhire.

Kütübî, Salâhuddîn Muhammed b. Şâkir ed-Dârânî. (1973). Fevâtü̈'l-Vefeyât. İhsân Abbâs (thk). (C.4). Beyrût.

Makrîzî, Ebü'l-Abbas Takıyyüddîn Ahmed b. Alî b. Abdülkâdir. (1991). Kitâbü'l-Mukaffe'l-kebîr. Muhammed el-Ya'lavî (thk). (C.6). Beyrût.

Müslim b. Haccâc. (2006). Sahihu Müslim. Ebû Kuteybe Nazar Muhammed el-Fâryâbî (thc). Riyâd.

Nesâî, Ebû Abdurrahmân Ahmed b. Alî b. Şuayb. (ty). es-Sünen. Riyâd.

Neşşâr, Alî Sâmî. (1984). Mebâhisu'l-Bahs inde Müfekkiri'l-İslâm. Beyrût.

Nevevî, Ebû Zekeriyâ Yahyâ b. Şeref. (2009). el-Erbaûne'n-Nebeviyye. Mekke.

Nevevî, Ebû Zekeriyâ Yahyâ b. Şeref. (1994). el-Minhâc fî Şerhi Sahîhi Müslim b. Haccâc. Beyrût.

Özel, A. İbn Dakîki'l-Î̃d. (1999). Diyanet Vakfı İslâm Ansiklopedisi içinde. (C.19, ss.407-9). Ankara.

Safedî, Ebu's-Safâ Selâhaddîn Halîl b. İzzuddîn Aybeg b. Abdullah. (2000). el-Vâfì bi'l-Vefeyât. Ahmed el-Arnâût ve Türkî Mustafâ (thk). Beyrût.

Süyûtî, Ebu'l-Fazl Celâleddîn Abdurrahmân b. Ebî Bekr. (1967). Hüsnü'l-muhâdara fì târîhi Mısır ve'l-Kâhire, Muhammed Ebu'l-Fazl İbrâhîm (thk). (C.1). Kâhire.

Sübkî, Abdülvehhâb b. Alî b. Abdülkâfî. (1964). Tabakâtu'ş-Şâfiiyyeti'l-Kübrâ. Mahmûd Muhammed et-Tanâhî-Abdülfattâh Muhammed el-Hulv (thk). (C.9). Kâhire.

Şensoy, S. (2010). Şerh. Diyanet İslâm Ansiklopedisi içinde. (C.38, ss.555-9). Ankara.

Şevkânî, Ebû Abdullah Muhammed b. Alî b. Muhammed Havlânî. (2012). el-Bedrü't-tâli' bi mehâsin men ba'de'l-karni's-sâbi'. (C.2). Kâhire.

Tirmizî, Muhammed b. Îsâ. (1968). es-Sünen. Ahmed Muhammed Şâkir (thk). Kâhire.

Topaloğlu, N. (2002). Ebü'l-Abbâs el-Kurtubî. ss.454-5. Diyanet İslâm Ansiklopedisi içinde. (C.26, ss.454-5). Ankara. 
Türcan, Z. (2008). Hadis Literatüründe Şerh Geleneği ve Özellikleri (Yayınlanmamış doktora tezi). Ankara Üniversitesi Sosyal Bilimler Enstitüsü, Ankara.

Türcan, Z. (2011). Anadolu'da hadis şerhçiliği. M. Düzenli (Ed.). Uluslararası Katılımlı Sempozyum: Anadolu'da Hadis Geleneği ve Daru'1-Hadisler Kongresi içinde (s. 339351). Samsun: Ondokuz Mayıs Üniversitesi.

Üdfüvî, Ebü'l-Fazl Ca'fer b. Sa'leb. (1966). et-Tâliu's-Saîd. Sa'd Muhammed Hasan (thk). Kâhire.

Yâfiî, Afîdüddîn Abdullah b. Es'ad b. Alî el-Yemânî. (1997). Mir'âtu'l-Cenân ve İbretü'l-Yakzân fì Ma'rifeti Havâdisi'z-Zamân. (C.4). Beyrût.

Zebîdî, Murtazâ. (1969). Tâcu'l-Arûs. Hüseyn Kassâr (thk). (C.6). Küveyt.

Zehebî Ebû Abdullah Şemsuddîn Muhammed b. Ahmed b. Osmân. (ty.). Tezkiratu'l-Huffâz. (C.4). Beyrût.

Zehebî Ebû Abdullah Şemsuddîn Muhammed b. Ahmed b. Osmân. (1988). el-Mu'cemu'lMuhtass. Muhammed Habîb Heyle (thk). Tâif. 